\title{
Context and Challenges Regarding the Environmental Certification of Soy Production in the Matopiba Region of Brazil
}

\author{
Antonio Carlos Reis de Freitas, Thiago Buosi \\ Brazilian Agricultural Research Corporation-Embrapa Cocais, São Luis, Brazil \\ Email: carlos.freitas@embrapa.br, thiago.buosi@embrapa.br
}

How to cite this paper: de Freitas, A.C.R. and Buosi, T. (2018) Context and Challenges Regarding the Environmental Certification of Soy Production in the Matopiba Region of Brazil. American Journal of Industrial and Business Management, 8, 2086-2101.

https://doi.org/10.4236/ajibm.2018.810138

Received: September 4, 2018

Accepted: October 6, 2018

Published: October 9, 2018

Copyright $\odot 2018$ by authors and Scientific Research Publishing Inc. This work is licensed under the Creative Commons Attribution International License (CC BY 4.0).

http://creativecommons.org/licenses/by/4.0/

\begin{abstract}
Brazil has become one of the world's largest grain producers and exporters by increasing productivity as well as expanding its agricultural frontiers in the last decades. Globally, the relevance of the consumer awareness of the need to preserve natural ecosystems is strengthened and consumer has demanded information from suppliers that demonstrate the sustainability of the productive chains. In the Matopiba region, the last agricultural frontier in the Brazilian Cerrado biome, soy producers are being encouraged to adhere to the responsible soy certification standard. This study evaluated three groups of certified soy producers. Field research has shown that farmers have common expectations: legitimacy, risk reduction, land valuation, and promotion of different modalities of access to the certification system.
\end{abstract}

\section{Keywords}

Private Governance, Sustainability Standards, Roundtables, Soy

\section{Introduction}

Brazil is among the world's largest grain producers. In 2016, the area planted with soybeans reached 33.3 million hectares and produced 96.296 million tons of grains. Since the early 2000s, the average annual variation in soybean area has been $18.4 \%$ in the Matopiba region, see Table A1 and Table A2. Economic growth understood as a linear, boundless process based on the continuous incorporation of land and natural resources is the presupposition of the frontier economy [1]. Thus, the expansion of soybean production has been marked by the incorporation of new areas in agricultural frontier regions, especially the Matopiba region, the economic importance of which has increased [2] due to 
the replacement of low-productivity pastures [3] and the suppression of native vegetation [4].

In the early 2000s, environmental organizations began to criticize soy producers for possible risks to the integrity of the Amazon biome as a result of the expansion of soybean crops. As a result, the Soy Moratorium was declared in July 2006, consisting of a commitment on the part of the Brazilian Association of Vegetable Oil Industries (ABIOVE) and the Brazilian Association of Cereal Exporters (ANEC) not to market or finance soybeans produced in areas that were deforested in the Amazon biome [5]. This moratorium represented an institutional innovation in environmental governance in Brazil, which was improved by the launching of the socio-environmental certification of the soybean chain, known as the Round Table Responsible Soy (RTRS) standard, in the Cerrado biome (savanna) [6].

Considering this context, the aim of the present study was to answer the following questions: What motivation could induce soy producers in agricultural frontier regions to adhere to certified agriculture standards? What barriers could hinder the adherence of soy producers to socio-environmental certification standards? What strategies are being adopted for certification? In this study, three groups of certified soy producers were evaluated. The field research shows that farmers have common expectations: legitimacy, risk reduction, land valuation, and the promotion of different modalities of access to the certification system. This paper presents the results of research conducted on the environmental certification of soybeans. The scenario of soybean expansion on the agricultural frontier of the Cerrado biome was delineated through documentary research and the strategies of the soybean producers were investigated during the fieldwork.

Qualitative research methods were used in the case study on the economic and institutional context of the implementation of the RTRS standard in the Matopiba region. A documental research was first carried out based on the "Brazilian National Interpretation of the RTRS Standard for Responsible Soy Production" document in order to understand its principles and requirements [6]. Field surveys were also conducted with producers in the region. The interviewees included three RTRS certified groups of producers (covering all producers on process of certification on RTRS in Matopiba). One representative (FAPCEN, SLC Agricola and Agrex do Brasil) of each multi-site considered in this work and six non-certified producers were interviewed. The interviews consisted of a survey with 50 questions divided into six sections: good agricultural practices, environmental responsibility, community relations, legal aspects, responsible working conditions and certification systems. In addition to this information, the survey included questions on property data, such as geographical coordinates, size and soy production in the 2014/2015 and 2016/2017 harvests. The interviews were conducted with producers and managers of farms located in the Matopiba region of Brazil. 


\section{Standards of Agricultural Production}

Production standards are persuasive mechanisms of international governance, the purpose of which is to achieve collective wellbeing through the coordination or constraint of individual behaviors [7]. From this perspective, standards are mechanisms that increase efficiency and cooperation between different actors (governments, companies and producers) and play different roles in response to economic, environmental or technological circumstances. Standards regulate procedures and behaviors expected to ensure public or private governance of a situation for which transformation on a local, national or global scale is desirable. The diversity of problems faced by production standards includes physical or technological externalities and regulatory externalities.

In the last twenty years, private standards have emerged in response to the evolution of the public regulation in the agri-food sector, especially in Europe, as an instrument of market governance in many countries [8]. Private standards are created by commercial or non-commercial private entities, such as companies, industry organizations, non-governmental organizations, etc. Standards are developed by coalitions of private sector actors and the role of governments is to enact and/or enforce them. Private standards have evolved in their institutional form, functions and attributes as part of a broad trend in value chain governance in the context of regulatory controls.

The main types of standards are those for risk management and product differentiation. The role of standards (public or private, compulsory or voluntary) is to facilitate the coordination of agri-food value chains at the interface between producers and firms, conveying credibility with regard to the nature of the products and the conditions under which they were produced, processed and transported.

Standards reflect the convergence of changes in consumer demands, regulatory systems and the modus operandi structure of the value chain, with emphasis on the characteristics of accreditation, the information costs of which are typically high [8]. Moreover, standards provide a mechanism by which the interpretation and verification of this information can be managed, that is, they establish a "common language" between buyers and sellers by describing product and process attributes, while reducing verification costs.

The following are the attributes of private standards: 1) voluntary nature: there is no legal obligation to comply with them, 2) private sector protagonism: the main functions are carried out by private entities, 3) compliance certified by a private organization: the role of the public sector is limited to the establishment of accreditation systems. Thus, private standards for product differentiation play roles such as coding information, managing interface complexities and reducing transaction costs.

The deliberative capacity of private environmental governance based on multiple stakeholders involves open, inclusive processes based on consensus, thus creating common good through communicative processes that allow the inclu- 
sion of a wide variety of stakeholders [9]. To be democratic, deliberation must be inclusive, authentic and consequent. Thus, inclusiveness refers to the variety of interests and discourses found in the governance arrangement and authenticity requires deliberation to be the result of a reflexive process with some level of reciprocity between the interested parties, consequently meaning that deliberations have an impact on collective decisions [10].

Since the 1990s there was a proliferation of variety and number of voluntary certification standards creates difficulties for producers and costumer to attend an appropriate standard and compliance due multiple standards [11] as well as a credibility gap, increased costs to gain certification by multiple Voluntary sustainability standards systems and a potential race to the bottom of systems. On other hand, mutual recognition and meta-regulation are two mechanisms which can facilitate the cooperation [12].

In this process, there has been a general lack of strategies linking different initiatives, which has led to more duplication of efforts, confusion and skepticism on the part of the consumer and raised questions about the legitimacy of these voluntary standards. This has pointed to the need for a broader coordination of efforts and multiple related initiatives, which has been defined by some authors as "meta-governance" [13].

Bruchem et al. [14] suggested a measurement framework to evaluate the effectiveness of the standards. In this way, it becomes operational to measure and compare standards. However, the context and impacts of certifications programs should be evaluated for rigorous approach in reporting methods and results considering there is no guarantee that living standards improve for farmers and workers [15]. After extensive academic review on voluntary certification standards for tropical agricultural commodities, DeFries et al. [16] concluded that voluntary certification programs have contributed to sustainable and effective development goals more than smolder farmers' income enhancement.

This Research have focuses on the RTRS voluntary certification standard which was established with the purpose of facilitating the global dialogue on economically viable, socially equitable and environmentally appropriate soybean production under the coordination of the International Responsible Soy Association, which was established in 2006 with stakeholders (producers, social organizations and companies). The RTRS organization includes 197 members from different countries, such as Argentina, Belgium, Bolivia, Brazil, Denmark, Spain, Finland, Netherlands, France, India, China, Singapore, Norway, Paraguay, Uruguay, United Kingdom, Sweden and Switzerland.

The responsible soy production standard is structured on five principles and 27 criteria that are required of producers interested in earning RTRS certification in a conventional, organic or genetically modified production process. This production standard has a total of 98 indicators, including requirements to conserve of "High Conservation Value Areas" (HCVA), promote good management practices, ensure fair working conditions and respect claims for land tenure. The 
need for the protection of HCVA is due to "biological, social, or cultural value of critical significance" [6].

To facilitate the adherence of producers to the certification standard, RTRS has established a progressive entry level that involves a continuous improvement approach. Thus, a classification of indicators based on three categories (immediate compliance indicators, short-term compliance indicators and medium-term compliance indicators) is used assess the conformity of a producer interested in certification [6].

Certified soybean businesses are still restricted to a few companies. Globally, there are 0.9 million hectares and 1.7 million tons of certified soybean in 2017/2018 harvest. Brazil has 143 certified producers (71.3\% of total production) and Argentina is in second position, with 48 producers (25.2\% of production), see Table A3. The production of certified soy in Brazil is concentrated in two regions: the State of Mato Grosso and the Matopiba region. The main buyers are the Netherlands and Scandinavian countries [17].

\section{The Context of Soy Moratorium and Its Reflections in Brazil and the Matopiba Region}

In the first half of the 2000s, soybean plantations reached 22 million hectares in Brazil and 1.8 million hectares in the Matopiba region. In the period between 2000 and 2016, the variation in planted area was $+143.2 \%$ in Brazil and $+321.1 \%$ in the Matopiba region, see Table A1 and Table A2. The expansion of soybean crops in the Matopiba region, especially in the states of Maranhão and Piauí, has occurred in areas occupied by native vegetation of the Cerrado biome [4], which once again provoked the criticism of environmentalists, see Figure 1.

Figure 1 shows that there was $-6.8 \%$ of inflection in the curve of the expansionist trend of soybean sector in the country in the years 2006 and 2007. This period coincides with the Soy Moratorium in the Amazon biome. The Soy Moratorium was a response to pressure by environmental groups (World

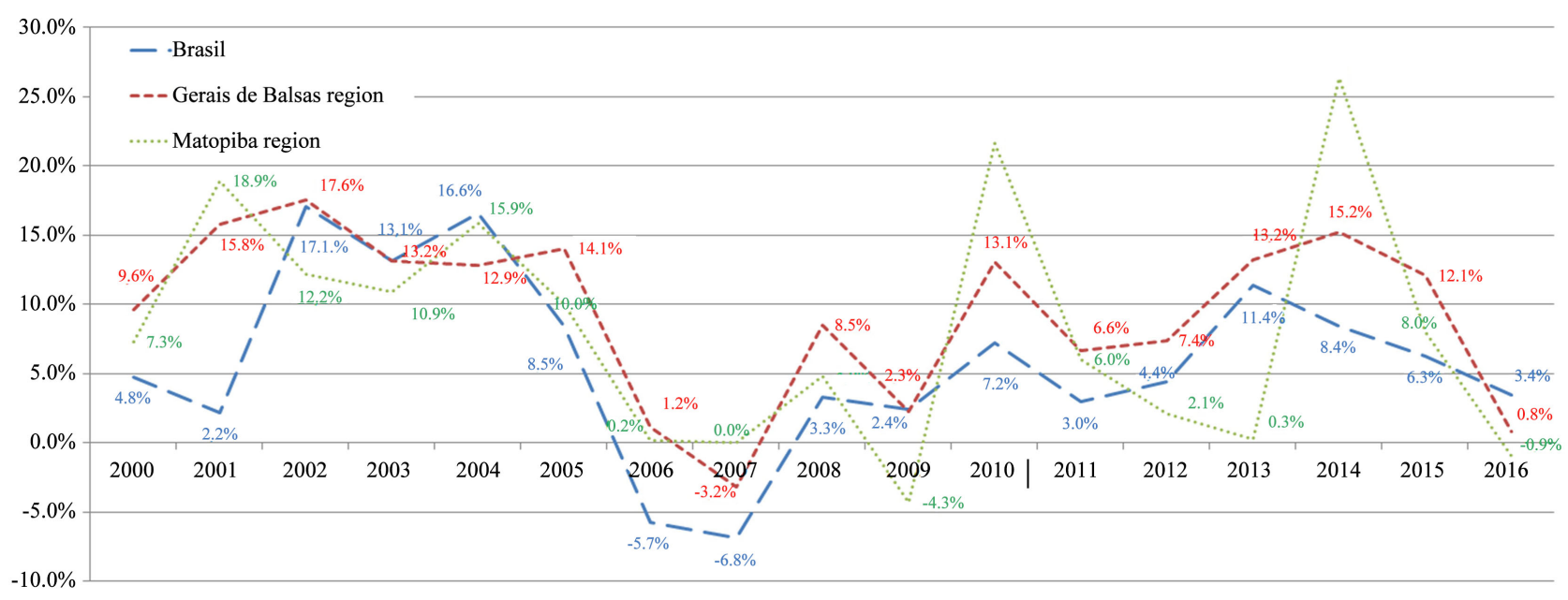

Figure 1. Annual percentage variation in planted area of soy in Brazil, Matopiba region and Gerais de Balsas region, Source: [18]. 
Wildlife Fund and Greenpeace) against the expansion of soybean production in Amazonian agricultural frontier regions, with the commitment of Brazilian environmental agency Instituto Brasileiro do Meio Ambiente e dos Recursos Naturais Renováveis (IBAMA) to intensify state control actions against illegal deforestation. The effectiveness of the Soy Moratorium as an environmental governance tool has limited impact without the strong performance of the national government [19]. Therefore, companies can fail with regard to their sustainability commitments in supply chains, since the success of private initiatives often depends on the support of public policies [20].

In November 2017, a pool of sixty environmental organizations, including the World Wildlife Fund, Greenpeace and The Nature Conservancy launched a manifesto in London, as a warning voice against the increase in deforestation of the Brazilian Cerrado. The manifesto was entitled "The Future of the Cerrado in the hands of the market: the deforestation and the conversion of native vegetation must stop". In the period from 2013 to 2015 there was an expansion of agribusiness in the Matopiba region, so that the environmental organizations indicated that the model of the Amazon Soy Moratorium should be replicated and expanded to contain the deforestation of the Cerrado. The following month (December 2017), the RTRS announced its full support for the manifesto, the major plea of which was "urgent measures to ensure that the supply chains for soy and beef do not contribute to deforestation and the conversion of natural areas for agricultural purposes" [6].

\section{Modalities of Private Governance Arrangements Adopted in the Matopiba Region}

Certified soybean farms in the Matopiba region are organized into three multi-sites. Multi-site certification refers to the process in which a single certificate involves multiple agricultural establishments, all of which are subject to the same administration and control systems [21]. These multi-sites consist of private arrangements for environmental governance that facilitate the producers' access to the certification process. In Matopiba region this strategy was identified among the producers on the process of certification.

Three different groups, each one following a specific approach or modality access were identified. The first, FAPCEN multisite, one is formed of multiple stakeholders and leaded by one organization. The second, SLC Agricola multisite, one is a single company managing the own process. The third, Agrex do Brasil multisite, one is formed of multiple farms integrated by their production's buyer and main supplier that drives the process of certification. Table 1 presents a summary of characteristics of these strategies and as it follows more information are presented about the fieldwork and these modalities adopted. Further, discussion on these results is presented.

The first modality (exemplified by the multi-site FAPCEN) regards the arrangement of multiple farms with a medium-scale of business operations. These 
farms seek to reduce the costs of certification by not individualizing environmental commitments. In this modality, an organization is responsible for managing the arrangement, while compliance is ensured by the members of the group in a supportive manner. Information obtained through interviews enabled the inference that this segment of producers exhibits weaknesses in its environmental performance, especially due to the high level of informality in the processes of monitoring and controlling the production of certified soy. In the second modality (exemplified by the multi-site SLC Agricola), the company acquires certification in an individualized way. In this case, the business model includes large-scale enterprises that have specialized sectors (technical assistance, production, storage, transport logistics and commercialization) and codes of conduct are used to monitor operational procedures and sustainability. The third modality (exemplified by Agrex do Brasil) regards an arrangement of multiple farms integrated into a Grain Purchasing Company and supplier of inputs, which has specialized services, such as technical assistance, warehousing, transportation and multimodal logistics.

The expected outcomes of these arrangements are market access, risk reduction, rural property valuation, premium pricing, reputation and legitimacy. These access modalities adopted by certified producers in the Matopiba region also include certified soy producers in the central-southern region of the country.

\subsection{FAPCEN Case}

The FAPCEN multi-site group is composed of nine farms: five in the state of Maranhão and four in Piauí. The area covered by the group is $188,074.36$ hectares, of which the certified soybean area is $119,423.38$ hectares (Table 2). Certification on the RTRS standard was obtained in 2016 and the certificate is valid until June 13, 2021. Under the terms of certification, the group will is audited annually to monitor compliance with all applicable certification requirements.

It should be noted that this multi-site was not certified under the chain of custody system. Thus, the monitoring of certified production units is more flexible. Its management is the responsibility of FAPCEN, which is responsible for ensuring that the farms fulfill the standards and requirements. There is a program of internal auditing defined in the group management manual, which consists of an initial internal audit on all farms and an annual monitoring audit to ascertain the compliance of the group members. Members of the FAPCEN multi-site demonstrate knowledge of applicable laws, hold the legal rights to use the land and apply appropriate management practices, according to the records consulted. The updated records relating to all the requirements of the standard are controlled by the manager of each farm and should be maintained for at least five years.

\subsection{SLC Agricola Case}

The SLC Agricola multi-site group consists of seven farms: two in the state of 
Maranhão, three farms in Mato Grosso, one in Bahia and one in Goiás. The total area is $267,499.72$ hectares, of which 139,695 hectares are planted and 0.4 million tons of soybeans are certified in the RTRS standard with validity up to August, 17, 2021 (Table 3).

SLC Agricola has a business model based on a modern production system, with a high scale, standardization of production units, state-of-the-art technology and socioenvironmental responsibility. The company is formed by different departments that support the group's farms and counts on external legal counseling. Using this structure, there was a coordinated action to incorporate practices and adapt procedures in order to give more transparency to the management of the processes [23].

\subsection{Agrex Do Brasil Case}

The Agrex multi-site group is formed by 22 farms: eleven in the state of Maranhão, five in Mato Grosso, four in Bahia and two in Piauí. The total area is $170,398.89$ hectares, of which $94,150.76$ hectares are planted and production is approximately 0.3 million tons of soybeans certified in the RTRS standard (Table 4).

The RTRS certification was obtained in the 2012/2013 cycle, making Agrex the pioneer in the region. The certification process required adjustments to the operation to meet requirements, namely, the maintenance of "High Conservation Value Areas", best practices, soil and water management, fair working conditions, respect for land tenure claims, the motivation of collaborators, strengthening relations with neighboring communities and support from external legal counseling.

\section{General Results of Fieldwork}

Interviews with ten certified and non-certified producers allowed the identification of barriers and facilitators in the scenario of socioenvironmental certification in the Matopiba region. Table 5 summarizes the main results.

Analyzing the results shown in Table 5 in relation to compliance with environmental/labor legislation and best practices, most producers stated that they recognized the existing environmental and labor legislation. However, there is a predominance of informality in the monitoring and control of the agricultural production process. On the other hand, farms interested in certification seek to comply with legislation through investments in infrastructure and/or the contracting of services specialized in legal issues and environmental licensing requirements. Regarding working conditions and compliance with labor legislation, Brazilian law is being fulfilled. Large companies celebrate formalized collective agreements.

State regulation is perceived by the interviewees as bureaucratic and costly. According to the interviewees: "it's hard to meet certain legal demands due to the difficulty in formalization, such as the documentation of employees, land, 
Table 1. Characteristics of RTRS multi-site initiatives in Matopiba region.

\begin{tabular}{|c|c|c|c|}
\hline $\begin{array}{l}\text { Actors involved in } \\
\text { socio-environmental } \\
\text { certification initiatives }\end{array}$ & Business model & Environmental performance & Outcomes expected \\
\hline $\begin{array}{l}\text { Multiple stakeholders } \\
\text { (e.g., FAPCEN) }\end{array}$ & $\begin{array}{l}\text { Collective environmental goals } \\
\text { Medium scale of soy cultivation } \\
\text { area (under 50,000 ha for farmland } \\
\text { associated) }\end{array}$ & $\begin{array}{l}\text { Weak transparency and traceability } \\
\text { Incomplete documentation }\end{array}$ & $\begin{array}{l}. \text { Legitimacy } \\
. \text { Market access } \\
. \text { Premium prices } \\
. \text { Efficient management of farm } \\
. \text { Reduced risk } \\
. \text { Valorization of rural property }\end{array}$ \\
\hline $\begin{array}{l}\text { Single company } \\
\text { (e.g., SLC Agricola) }\end{array}$ & $\begin{array}{l}\text { High technology of production } \\
\text { system } \\
\text {. Large scale of soy cultivation area: } \\
\text { over } 100,000 \text { ha for farmland } \\
\text { integrated }\end{array}$ & $\begin{array}{l}\text { Transparency and traceability } \\
\text { Publication of annual sustainability report } \\
\text {. Adoption of codes of conduct and operational } \\
\text { guide } \\
\text {. Appropriate documentation: soil management. } \\
\text { plan, pesticide use plan, computation } \\
\text { monitoring system, water quality control, fuel } \\
\text { consumption monitoring, native vegetation } \\
\text { monitoring }\end{array}$ & $\begin{array}{l}\text { Reputation } \\
\text { Reduced risk } \\
\text {. Valorization of property rights } \\
\text {. Market share }\end{array}$ \\
\hline $\begin{array}{l}\text { Integrated Trader company } \\
\text { (e.g., Agrex do Brasil) }\end{array}$ & $\begin{array}{l}\text { Future market: purchases grain } \\
\text { and sells fertilizers, seeds and } \\
\text { pesticides } \\
\text {. Varied scales of soy cultivation } \\
\text { area: less than } 5000 \text { ha up to } 50,000 \\
\text { ha for farmland integrated } \\
\text {. Platform of services: warehouse, } \\
\text { transport, trader, specialized } \\
\text { technical assistance, multimodal } \\
\text { logistics }\end{array}$ & $\begin{array}{l}\text { Transparency and traceability } \\
\text {. Adoption of codes of conduct and operational } \\
\text { guide } \\
\text {. Appropriate documentation: soil management } \\
\text { plan, pesticide use plan, computation } \\
\text { monitoring system, water quality control, fuel } \\
\text { consumption monitoring, native vegetation } \\
\text { monitoring. }\end{array}$ & $\begin{array}{l}\text { Reputation } \\
\text {. Market share } \\
\text { Motivation for workers } \\
\text {.International compliance } \\
\text {. Purchasing companies seek to } \\
\text { access markets and international } \\
\text { credit lines }\end{array}$ \\
\hline
\end{tabular}

Source: Interviews during fieldwork.

Table 2. Total area, planted area and certified soybean production of FAPCEN multi-site group.

\begin{tabular}{|c|c|c|c|c|c|c|}
\hline \multirow{2}{*}{ Name of the Farm } & \multirow{2}{*}{ Location } & \multicolumn{2}{|c|}{ Geographic Coordinates } & \multirow{2}{*}{ Total area (ha) } & \multirow{2}{*}{ Planted area (ha) } & \multirow{2}{*}{$\begin{array}{c}\text { Total } \\
\text { Production }(\mathrm{t})\end{array}$} \\
\hline & & Latitude (S) & Longitude (W) & & & \\
\hline Fazenda Sol Nascente & Maranhão & $7^{\circ} 27^{\prime} 10.44^{\prime \prime}$ & $46^{\circ} 01^{\prime} 38.45^{\prime \prime}$ & 112.63 & 71.4 & 214.20 \\
\hline Fazenda Nova Holanda & Maranhão & $8^{\circ} 24^{\prime} 56.00^{\prime \prime}$ & $46^{\circ} 21^{\prime} 81.40^{\prime \prime}$ & $51,565.27$ & $34,668.51$ & $104,005.53$ \\
\hline Fazenda Tunísia & Piauí & $7^{\circ} 26^{\prime} 20.07^{\prime \prime}$ & $44^{\circ} 20^{\prime} 45.29^{\prime \prime}$ & $12,247.07$ & 8353.73 & $25,061.19$ \\
\hline Fazenda Progresso & Piauí & $7^{\circ} 30^{\prime} 14.43^{\prime \prime}$ & $44^{\circ} 12^{\prime} 34.43^{\prime \prime}$ & $27,751.64$ & $18,049.93$ & $54,149.79$ \\
\hline Fazenda Serra Vermelha & Maranhão & $6^{\circ} 53^{\prime} 39.56^{\prime \prime}$ & $45^{\circ} 19^{\prime} 32.30^{\prime \prime}$ & $22,950.21$ & $14,359.43$ & $58,586.47$ \\
\hline Fazenda Santa Luzia & Maranhão & $8^{\circ} 24^{\prime} 56.00^{\prime \prime}$ & $45^{\circ} 29^{\prime} 52.77^{\prime \prime}$ & $14,477.00$ & 5975.74 & $22,588.29$ \\
\hline Fazenda Boa Esperança & Piauí & $7^{\circ} 26^{\prime} 20.07^{\prime \prime}$ & $45^{\circ} 19^{\prime} 59.30^{\prime \prime}$ & $18,901.29$ & $14,115.91$ & $55,052.05$ \\
\hline Fazenda Ribeirão & Piauí & $7^{\circ} 30^{\prime} 14.43^{\prime \prime}$ & $44^{\circ} 12^{\prime} 34.43^{\prime \prime}$ & $33,627.09$ & $20,029.92$ & $66,098.73$ \\
\hline \multirow[t]{2}{*}{ Fazenda Alice } & Maranhão & $7^{\circ} 37^{\prime} 16.64^{\prime \prime}$ & $45^{\circ} 41^{\prime} 47.32^{\prime \prime}$ & 6442.16 & 3798.81 & $13,217.04$ \\
\hline & Total & & & $188,074.36$ & $119,423.38$ & $398,973.29$ \\
\hline
\end{tabular}

Source: [22]. 
Table 3. Total area, planted area and certified soybean production of SLC Agricola multi-site group.

\begin{tabular}{|c|c|c|c|c|c|c|}
\hline \multirow{2}{*}{ Name of the Farm } & \multirow{2}{*}{ Location } & \multicolumn{2}{|c|}{ Geographic Coordinate } & \multirow{2}{*}{$\begin{array}{c}\text { Total area } \\
\text { (ha) }\end{array}$} & \multirow{2}{*}{$\begin{array}{l}\text { Planted area } \\
\text { (ha) }\end{array}$} & \multirow{2}{*}{$\begin{array}{c}\text { Total } \\
\text { Production (t) }\end{array}$} \\
\hline & & Latitude (S) & Longitude (W) & & & \\
\hline Fazenda Parnaíba & Maranhão & $08^{\circ} 30^{\prime} 50.82^{\prime \prime}$ & $46^{\circ} 04^{\prime} 40.38^{\prime \prime}$ & $75,394.07$ & $35,774.56$ & $110,901.14$ \\
\hline Fazenda Planeste & Maranhão & $08^{\circ} 33^{\prime} 13.97^{\prime \prime}$ & $46^{\circ} 51^{\prime} 33.48^{\prime \prime}$ & $55,134.55$ & $24,137.14$ & $74,825.13$ \\
\hline Fazenda Planalto & Mato Grosso do Sul & $18^{\circ} 12^{\prime} 39.71^{\prime \prime}$ & $53^{\circ} 12^{\prime} 12.42^{\prime \prime}$ & $17,437.32$ & 6418.41 & $19,832.89$ \\
\hline Fazenda Pamplona & Goiás & $16^{\circ} 13^{\prime} 38.70^{\prime \prime}$ & $47^{\circ} 37^{\prime} 33.64^{\prime \prime}$ & $17,384.66$ & 8259.26 & $25,603.71$ \\
\hline Fazenda Panorama & Bahia & $13^{\circ} 24^{\prime} 29.77^{\prime \prime}$ & $46^{\circ} 05^{\prime} 46.62^{\prime \prime}$ & $34,003.87$ & $10,968.99$ & $34,003.87$ \\
\hline Fazenda Paiaguás & Mato Grosso & $14^{\circ} 04^{\prime} 50.62^{\prime \prime}$ & $57^{\circ} 27^{\prime} 18.70^{\prime \prime}$ & $44,706.10$ & $34,257.10$ & $106,171.49$ \\
\hline \multirow[t]{2}{*}{ Fazenda Planorte } & Mato Grosso & $13^{\circ} 56^{\prime} 10.22^{\prime \prime}$ & $58^{\circ} 53^{\prime} 39.60^{\prime \prime}$ & $23,439.15$ & $19,879.54$ & $61,427.78$ \\
\hline & Total & & & $267,499.72$ & $139,695.00$ & $432,766.00$ \\
\hline
\end{tabular}

Source: [22].

Table 4. Total area, planted area and certified soybean production of Agrex do Brasil multi-site group.

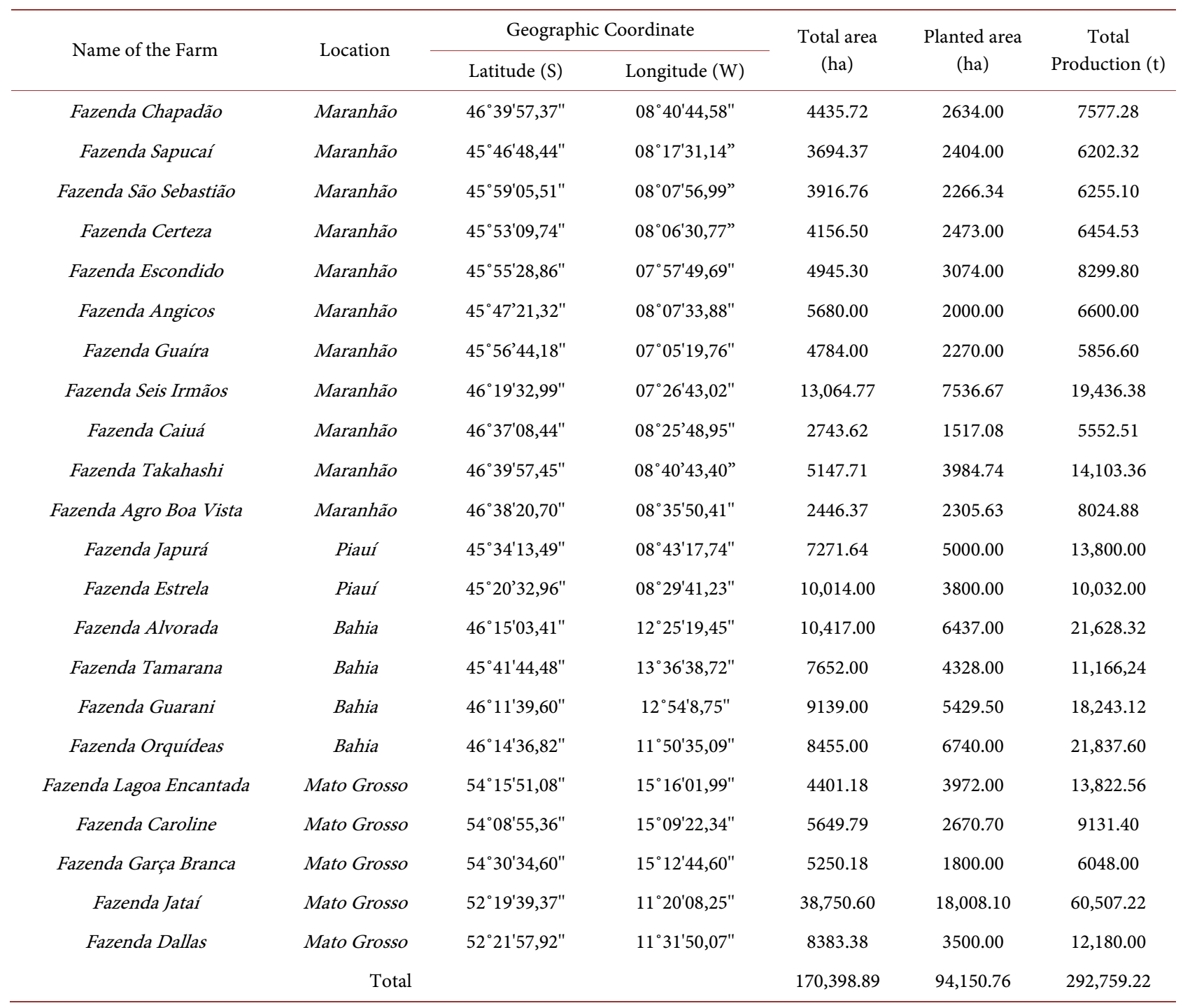

Source: [22]. 
Table 5. Synthesis of results obtained in interviews with producers.

\section{RESULTS FROM THE SURVEY APPLIED IN THE INTERVIEWS}

\section{Principle: Compliance with environmental legislation and best practices}

Barriers: Proof of legal compliance of farms is hampered by the informality of most operations, the producers have a perception of the state inoperability in the environmental regulation considering it onerous, farms need to bear high compliance costs in order to qualify for the socio-environmental certification process.

Facilitators: most interviewees recognize environmental legislation: the Forest Code, environmental licensing rules, the Phytosanitary Legislation and the Legislation on the use of agrochemicals, contracting legal advice to ensure legal compliance of farms, service of reverse logistics, adequacy of properties through investment in infrastructure, and legal compliance

\section{Principle: Responsible working conditions}

Barriers: Outsourced workers - high turnover, qualification/training costs, control of the supply of individual safety equipment by outsourced companies.

Facilitators: Compliance with labor legislation, collective bargaining agreements with the consent of a working class representative (FETAEMA - Union of agricultural workers of the state of Maranhão).

\section{Principle: Community Relations}

Barriers: Low regularity in communication between farms and local communities in the surrounding area,

Facilitators: Lack of conflict between certified farms and local communities, hiring of workers in the region to carry out farm activities, development of programs for the benefit of surrounding communities, such as: child education, family health, community gardens, training in agricultural practices ("field days"), disposal of equipment to prepare and harvest community agricultural fields, sharing equipment for the maintenance of bridges and roads.

\section{Principle: Agricultural Best Practices}

Barriers: Incomplete documentation of the application of pesticides, interviewee's claim "the size of the property makes it difficult to implement the application plan according to the agronomic prescription and control by order of service - SAP system (packaging according to legislation)", biological control of pests practiced by a few enterprises (allegations of "high operating cost" and "lack of trained personnel to carry out integrated pest management"), and the use of transgenic seeds is a widespread practice in the prevention of new diseases.

Facilitators: agricultural management based on the use of no-till systems, mapping of soil types for soil quality and erosion control, application of preservation practices (terrace, crop rotation and recovery of degraded soils), and replacement of native vegetation when recommended by the environmental license.

Source: Interviews during fieldwork.

lease agreements, etc.", "There are too many laws", "It is very complex to follow the changes in the laws", "It's very expensive to maintain employees or outsourced companies only to keep up with changes in the laws", "There are no qualified human resources or companies in the region that can provide adequate support in monitoring the laws." Some interviewees complained about the high cost of environmental impact studies and expressed dissatisfaction with the state environmental agency: "Bureaucracy that makes environmental licensing difficult", "There is a lack of information from the environmental agency."

Regarding the adoption of good agricultural practices, most interviewees adopt practices based on no-tillage systems, perform soil sampling for evaluation of fertility and recommendation for fertilization, control soil quality and erosion, and replace native vegetation when required by the environmental license. However, integrated pest management is not yet a widespread practice due to the operational difficulty (monitoring and controlling introduced invasive species or new pests) in performing this practice adequately. Another issue the interviewees mention regards the low availability of skilled labor to carry out the management operations and the use of herbicides, fungicides and insecticides for the control of Helicoverpa armigera and Anthonomus grandis (boll weevil) 
on cotton. However, farms promote training to minimize this demand for skilled labor. The scale of the operation can be a restrictive factor for the adoption of some of these practices due to the associated operational costs. A study by Nassar et al. [24] corroborates this statement: "For medium and small producers, integrated pest management means increasing costs for the technical training of workers and possibly hiring new workers to manage this activity in the field and analyzing the information."

Regarding the risk control of environmental contamination, the interviewees stated that they are constantly measuring the quantity of water used and that they carry out evaluation and quality control processes for surface and groundwater. The interviewees stated that they have a prevention plan to avoid the drift of agrochemicals to neighboring areas and monitor climatic conditions (wind direction, humidity, rainfall, etc.), time of application (night), range of vegetation, application of land-based defensive equipment. However, no interviewee presented information on the procedures and/or methods employed. According to auditing reports, the lack of control regarding the risks of environmental contamination also applies to certified producers: "There is no evidence of appropriate scale monitoring to demonstrate that the practices are effective in minimizing diffuse and localized impacts on the quality of surface and groundwater due to chemical residues, fertilizers, erosion or other sources, and to encourage the recharging of aquifers" [22] The interviewees stated that they adopt prevention plans and monitor climatic conditions, range of vegetation, application of land-based defensive products and other tools.

\section{Conclusions}

This study elucidates characteristics of the socio-environmental certification initiatives of the soybean chain in the Matopiba region of Brazil, which are guided by common motivations of the stakeholders: grain farms seek legitimacy, risk reduction and the valorization of their properties, and purchasing companies seek access to markets and international credit lines. Scale (size of the operation) is one of the factors that conform to the modalities or strategies of access to the soy environmental certification system. The fieldwork enabled the identification of three different strategies.

The first strategy involves initiatives based on multi-farm and medium-scale operations that focus on reducing the costs of certification and the nonindividualization of environmental commitments. Businesses that have chosen this strategy generally exhibit a high degree of informality in the control of operations as well as a lack of transparency and traceability of production processes, diffuse commitments/responsibilities and weak sustainability.

The second strategy (based on governance arrangements) has been subjected to standardized business models and high technology based operations. Such operations are more competitive, use cutting-edge technologies, seek the recovery of their lands and use computational platforms for the control and monitor- 
ing of the production process. These companies annually publish a sustainability report, adopt control codes that regulate most of the operational procedures and, consequently, offer better protection and traceability of their operations.

The third strategy refers to an arrangement of multiple farms integrated with a company or groups of companies with different scales of operations. The leading organization arranges specialized services, such as technical assistance, warehousing, transportation and multimodal logistics.

Barriers were also identified in this work. The main barriers are related to the costs on the process of identify and apply requirements to the practices and implementing controls, human resources and scale of the operation, and are presented on Table 5.

The analysis of the present results enabled a better understanding of the socio-environmental certification of soybean production in the Matopiba region as well as the proposal of an initial framework identifying strategies and some related trends. However, it is necessary to deepen the characterization of this framework, scenarios, indicated trends, relationships, costs, difficulties and alternatives for producers. Mapping and understanding these scenarios, dynamics and constraints are essential to the identification of barriers regarding the role of the public sector in facilitating this process and coming up with models and strategies that can facilitate the socio-environmental certification process and thus increase the number of certified producers in the Matopiba region as well as other regions of Brazil.

\section{Acknowledgements}

The authors are grateful to FAPEMA for funding this research.

\section{Conflicts of Interest}

The authors declare no conflicts of interest regarding the publication of this paper.

\section{References}

[1] Boulding, K. (1966) The Economics of Coming Space-Ship Earth. In: Environment Quality in a Growing Economy, Baltimore, John Hopkins.

[2] The Economist (2013) Brazil's Agricultural Miracle: How to Feed the World. http://www.economist.com/node/16889019/print

[3] Bolfe, E.L., de Victória, D. C., Contini, E., Bayma-Silva, G., Spinelli-Araujo, L. and Gomes, D. (2016) Matopiba em crescimento agrícola Aspectos territoriais e socioeconômicos. Revista de Política Agrícola, Brasília. Ano XXV-No. 4-Out./Nov./Dez. 2016.

[4] Filho, C. and Costa, K. (2016) A Expansão da Soja no Cerrado Caminhos para a ocupação territorial, uso do solo e produção sustentável. Agroicone, INPUT/2016.

[5] ABIOVE (2010) Moratória da soja: $4^{\circ}$ Ano do Mapeamento e Monitoramento do Plantio de Soja no Bioma Amazônia.

[6] RTRS (2017)

http://www.responsiblesoy.org/strong-support-for-urgent-action-in-brazils-cerrado 
/?lang=pt

[7] Abbott, K.W. and Snidal, D. (2010) International "Standards" and International Governance. Journal of European Public Policy, 8, 345-370.

https://doi.org/10.1080/13501760110056013

[8] Henson, S. and Humphrey (2010) Understanding the Complexities of Private Standards in Global AgriFood Chains.

[9] Schouten, G., Leroy, P. and Greetje, P.G. (2012) On the Deliberative Capacity of Private Multi-Stakeholder Governance: The Roundtables on Responsible Soy and Sustainable Palm Oil. Ecological Economics, 83, 42-50. https://doi.org/10.1016/j.ecolecon.2012.08.007

[10] Dryzek, J.S. (2009) Democratization as Deliberative Capacity Building. Comparative Political Studies, 42, 1379-1402. https://doi.org/10.1177/0010414009332129

[11] UNFSS (2016) Voluntary Sustainability Standards: Today's Landscape of Issues \& Initiatives to Achieve Public Policy Objectives. United Nations Forum on Sustainability Standards, New York.

[12] Marx, A. and Wouters, J. (2016) Competition and Cooperation in the Market of Voluntary Sustainability Standards. UNFSS Discussion Papers 3, United Nations Forum on Sustainability Standards, New York.

[13] Derkx, B. (2016) Meta-Governance in the Realm of Voluntary Sustainability Standards: Early Experiences and Their Implications. UNFSS Discussion Papers 1, United Nations Forum on Sustainability Standards, New York.

[14] Bruchem, V., Bruijne, W. and Reintjes, J. (2007) A Roadmap to Standard Effectiveness: Analyzing the Scope, Specificity and Compliance of Retail Standards. Erasmus University Rotterdam, Rotterdam.

[15] Oya, C., Schaefer, F., Skalidou, D., Mccosker, C. and Langer, L. (2017) Effects of Certification Schemes for Agricultural Production on Socio-Economic Outcomes in Low- and Middle-Income Countries: A Systematic Review. 3ie Systematic Review 34. International Initiative for Impact Evaluation (3ie), London.

[16] DeFries, R.S., Fanzo, J., Mondal, P., Remans, R. and Wood, S.A. (2017) Is Voluntary Certification of Tropical Agricultural Commodities Achieving Sustainability Goals for Small-Scale Producers? A Review of the Evidence. Environmental Research Letters, 12, Article ID: 033001. https://doi.org/10.1088/1748-9326/aa625e

[17] RTRS (2018a) RTRS Trading Platform. http://www.responsiblesoy.org/mercado/volumenes-y-productores-certificados/

[18] IBGE (2018). https://www.ibge.gov.br/estatisticas-novoportal/economicas/agricultura-e-pecuaria

[19] Brown, J.C. and Koeppe, M. (2014) Moratória da soja na Amazônia brasileira e governança ambiental: Regulação através do mercado ou regulação estatal? Revista Pós Ciências Sociais, 11.

[20] Lambin, et al. (2018) The Role of Supply-Chain Initiatives in Reducing Deforestation. Nature Climate Change, 8, 109-116.

https://doi.org/10.1038/s41558-017-0061-1

[21] RTRS (2014) Padrão RTRS de Certificação Grupal e Multi-site V 3.0.

[22] RTRS (2018) Public Audit Reports.

[23] SLC Agrícola (2016) Relatório de Sustentabilidade 2016.

[24] Nassar, A. and Antoniazzi, L.B. (2011) Análise Estratégica para Produção de Soja Responsável no Brasil e na Argentina. Instituto de Estudo do Comércio e Negociações Internacionais. 


\section{Appendix}

Table A1. Soy production in Brazil, Matopiba region and Gerais de Balsas region.

\begin{tabular}{|c|c|c|c|c|c|}
\hline \multirow{2}{*}{ Year } & \multicolumn{3}{|c|}{ Production (ton) } & \multicolumn{2}{|c|}{ Participation on Brazilian production (\%) } \\
\hline & Brazil & Matopiba region & Gerais de Balsas region & Matopiba region & Gerais de Balsas region \\
\hline 1990 & $19,897,804$ & 260,638 & 3003 & 1.31 & 0.02 \\
\hline 1991 & $14,937,806$ & 460,797 & 7207 & 3.08 & 0.05 \\
\hline 1992 & $19,214,705$ & 516,003 & 13,893 & 2.69 & 0.07 \\
\hline 1993 & $22,590,978$ & 709,252 & 46,780 & 3.14 & 0.21 \\
\hline 1994 & $24,931,832$ & $1,082,015$ & 81,199 & 4.34 & 0.33 \\
\hline 1995 & $25,682,637$ & $1,291,956$ & 99,119 & 5.03 & 0.39 \\
\hline 1996 & $23,166,874$ & 874,049 & 97,667 & 3.77 & 0.42 \\
\hline 1997 & $26,392,636$ & $1,320,900$ & 169,957 & 5.00 & 0.64 \\
\hline 1998 & $31,307,440$ & $1,651,387$ & 220,565 & 5.27 & 0.70 \\
\hline 1999 & $30,987,476$ & $1,755,116$ & 289,214 & 5.66 & 0.93 \\
\hline 2000 & $32,820,826$ & $2,208,221$ & 319,688 & 6.73 & 0.97 \\
\hline 2001 & $37,907,259$ & $2,215,224$ & 347,598 & 5.84 & 0.92 \\
\hline 2002 & $42,107,618$ & $2,361,061$ & 396,956 & 5.61 & 0.94 \\
\hline 2003 & $51,919,440$ & $2,901,441$ & 447,393 & 5.59 & 0.86 \\
\hline 2004 & $49,549,941$ & $4,309,803$ & 583,387 & 8.70 & 1.18 \\
\hline 2005 & $51,182,074$ & $4,863,654$ & 642,103 & 9.50 & 1.25 \\
\hline 2006 & $52,464,640$ & $4,209,519$ & 565,194 & 8.02 & 1.08 \\
\hline 2007 & $57,857,172$ & $4,639,706$ & 717,140 & 8.02 & 1.24 \\
\hline 2008 & $59,833,105$ & $5,723,866$ & 751,564 & 9.57 & 1.26 \\
\hline 2009 & $57,345,382$ & $5,293,391$ & 733,055 & 9.23 & 1.28 \\
\hline 2010 & $68,756,343$ & $6,295,111$ & 814,585 & 9.16 & 1.18 \\
\hline 2011 & $74,815,447$ & $7,421,472$ & 926,971 & 9.92 & 1.24 \\
\hline 2012 & $65,848,857$ & $7,372,474$ & 986,166 & 11.20 & 1.50 \\
\hline 2013 & $81,724,477$ & $6,826,109$ & 890,572 & 8.35 & 1.09 \\
\hline 2014 & $86,760,520$ & $8,664,902$ & $1,091,044$ & 9.99 & 1.26 \\
\hline 2015 & $97,464,936$ & $10,804,229$ & $1,192,245$ & 11.09 & 1.22 \\
\hline 2016 & $96,296,714$ & $7,066,662$ & 562,029 & 7.34 & 0.58 \\
\hline
\end{tabular}

Source: [18].

Table A2. Planted area of soy in Brazil, Matopiba region and Gerais de Balsas region.

\begin{tabular}{ccccccc}
\hline & \multicolumn{3}{c}{ Planted area of soy (ha) } & & \multicolumn{2}{c}{ Annual percentage variation on planted area (\%) } \\
\cline { 2 - 6 } Year & Brazil & Matopiba region & $\begin{array}{c}\text { Gerais de Balsas } \\
\text { region }\end{array}$ & Brazil & Matopiba region & $\begin{array}{c}\text { Gerais de Balsas } \\
\text { region }\end{array}$ \\
\hline 1999 & $13,069,793$ & 825,389 & 117,767 & & & \\
2000 & $13,693,677$ & 904,995 & 126,370 & 4.77 & 9.64 & 7.31 \\
\hline
\end{tabular}




\section{Continued}

\begin{tabular}{|c|c|c|c|c|c|c|}
\hline 2001 & $13,988,351$ & $1,048,263$ & 150,312 & 2.15 & 15.83 & 18.95 \\
\hline 2002 & $16,376,035$ & $1,232,485$ & 168,677 & 17.07 & 17.57 & 12.22 \\
\hline 2003 & $18,527,544$ & $1,394,913$ & 187,101 & 13.14 & 13.18 & 10.92 \\
\hline 2004 & $21,601,340$ & $1,574,420$ & 216,774 & 16.59 & 12.87 & 15.86 \\
\hline 2005 & $23,426,756$ & $1,795,921$ & 238,552 & 8.45 & 14.07 & 10.05 \\
\hline 2006 & $22,082,666$ & $1,817,113$ & 239,050 & -5.74 & 1.18 & 0.21 \\
\hline 2007 & $20,571,393$ & $1,759,430$ & 239,050 & -6.84 & -3.17 & 0.00 \\
\hline 2008 & $21,252,721$ & $1,909,612$ & 250,525 & 3.31 & 8.54 & 4.80 \\
\hline 2009 & $21,761,782$ & $1,953,154$ & 239,679 & 2.40 & 2.28 & -4.33 \\
\hline 2010 & $23,339,094$ & $2,208,973$ & 291,505 & 7.25 & 13.10 & 21.62 \\
\hline 2011 & $24,032,410$ & $2,355,529$ & 308,997 & 2.97 & 6.63 & 6.00 \\
\hline 2012 & $25,090,559$ & $2,529,124$ & 315,603 & 4.40 & 7.37 & 2.14 \\
\hline 2013 & $27,948,605$ & $2,863,919$ & 316,407 & 11.39 & 13.24 & 0.25 \\
\hline 2014 & $30,308,231$ & $3,300,064$ & 399,894 & 8.44 & 15.23 & 26.39 \\
\hline 2015 & $32,206,387$ & $3,700,009$ & 431,976 & 6.26 & 12.12 & 8.02 \\
\hline 2016 & $33,309,865$ & $3,729,161$ & 427,996 & 3.43 & 0.79 & -0.92 \\
\hline
\end{tabular}

Source: [18].

Table A3. RTRS certified soy production Worldwide, Brazil and Matopiba region.

\begin{tabular}{|c|c|c|c|}
\hline Country & & Production (1000 t) & Participation on production worldwide (\%) \\
\hline \multirow[t]{9}{*}{ Brazil } & & 1739.83 & 66.25 \\
\hline & Matopiba region & 809.77 & 30.83 \\
\hline & Maranhão & 478.70 & 18.23 \\
\hline & Bahia & 106.88 & 4.07 \\
\hline & Piaui & 224.19 & 8.54 \\
\hline & Mato Grosso & 842.62 & 32.08 \\
\hline & Goiás & 55.73 & 2.12 \\
\hline & Mato Grosso do Sul & 19.83 & 0.76 \\
\hline & Minas Gerais & 11.87 & 0.45 \\
\hline Argentina & & 662.45 & 25.22 \\
\hline Paraguai & & 64.12 & 2.44 \\
\hline China & & 62.93 & 2.40 \\
\hline India & & 54.27 & 2.07 \\
\hline Canadá & & 30.15 & 1.15 \\
\hline USA & & 8.19 & 0.31 \\
\hline Uruguai & & 4.34 & 0.17 \\
\hline TOTAL & & 2626 & 100 \\
\hline
\end{tabular}

Source: [22]. 